causes confusion among those trying to interpret their results. Is Mononychus a bird, a dinosaur, a bird-like dinosaur or a dinosaur-like bird? For Perle et al., judging by the title and first few lines of their paper ${ }^{1}$, it is a member both of birds (a monophyletic group) and dinosaurs (a nonmonophyletic group). For journalists, 'dinosaur' is more interesting than 'bird', and so we get 'bird-like dinosaur', just as the extinct stem-group mammals were long known as 'mammal-like reptiles'. Both usages are falsely inverted, giving the strength of the noun to the non-group (dinosaur, reptile) and the weakness of the adjective to the natural group (bird, mammal); 'dinosaur-like bird' and 'reptile-like mammal' correctly indicate inferred relationships.

In mammals, the proliferation of names for stem-group taxa that Hennig anticipated is now manifest ${ }^{7,8}$ because, as with birds, restriction of the name Mammalia to the crown group is being advocated ${ }^{9,10}$. Asked when mammals first appeared, a supporter of this procedure might respond with an age ranging over about 160 million years ${ }^{11}$, from early Cretaceous, the inferred age of the earliest monotremes and therians (method 1), through a range of intermediate dates (method 3) ${ }^{12}$ to the late Carboniferous (method 2), when the mammals are inferred to have separated from their Recent sister-group. For birds, a similar, though less extensive, range of dates might be offered. Advocates of methods 1 or 3 may thus provide misleading responses. The molecular biologist, for example, does not want to know when monotremes or ratites first appeared (method 1), or when ear ossicles or feathers first appeared (method 3). Instead, he or she wants to know when mammals (or birds) separated from their Recent sistergroup (method 2) as the basis for estimates of rates of molecular evolution or for calibration of molecular clocks. Hennig favoured method 2 for theoretical and practical reasons; within that method, there are strategies that avoid proliferation of names for stem-group taxa ${ }^{13,14}$. Surely it is time we palaeontologists agreed to avoid further needless proliferation of names and misleading inferences, and settled, with Hennig, on his method 2.

\section{Colin Patterson}

Department of Palaeontology,

The Natural History Museum,

London SW7 5BD, UK

1. Perle, A., Norell, M. A., Chiappe, L. M. \& Clark, J. M. Nature 362, 623-626 (1993)

2. Gauthier, J. Mem. Calif. Acad. Sci. 8. 1-56 (1986)

3. Chiappe, L. M. in 3rd Symp. Soc. Avian Paleontology and Evolution (ed. Peters, D. S.) (Senckenberghiana, in the press)

4. Hennig W Die Stammesgeschichte der insekten (Kramer, Frankfurt, 1969)

5. Hennig, W. Insect Phylogeny (Wiley, Chichester, 1981; translation of ref. 4 , with commentary).

6. Jefferies, R. P. S. in The Origin of Major Invertebrate Groups (ed. House, M. R.) 443-477 (Academic, London. 1979)

7. McKenna, M. C. in Toward a Phylogenetic Classification of the Mammalia (eds Luckett, W. P. \& Szalay, F. S.) 21-46 (Plenum, New York, 1975)

Rowe, T. J. Vert. Paleont. 8, 241-264 (1988)

9. Gauthier, J., Kluge, A. G. \& Rowe, T. Cladistics 4 105-209 (1988)

10. De Queiroz, K. \& Gauthier, J. A. Rev. ecol. Syst. 23 449-480 (1992)

11. Benton, M. J. J. molec. Evol. 30, 409-424 (1990)

12. Rowe. T. \& Gauthier, J. Syst. Biol. 41, 372-378 (1992)

13. Patterson, C. \& Rosen, D. E. Bull. Am. Mus. Nat. Hist. 158, 81-172(1977).

14. Wiley, E. O. Phytogenetics (Wiley, New York, 1981)

\title{
Cell checkpoint and radiosensitivity
}

SIR - Recent studies highlighting the role of p53 protein in cell-cycle regulation have heightened interest in the importance of cell-cycle checkpoints in mammalian cell responses to DNA damage. Cells with altered or absent p53 protein show increased genomic instability ${ }^{1}$ and, after exposure to ionizing radiation, a much reduced delay in the G1 phase of the cell cycle $^{2,3}$. It has been suggested that the increased genomic instability results from the reduced G1 delay and the cell's subsequent failure to repair DNA damage before it attempts DNA replication in $\mathrm{S}$ phase $^{4}$. This sensitivity to DNA damage should result in greater frequencies of radiation-induced cell killing and chromosome damage. However, evidence from studies of cells treated with caffeine, cells derived from patients with ataxiatelangiectasia (AT), transformed cell lines and tumour cells strongly suggests that the $\mathrm{G} 1$ checkpoint plays little or no role in determining the sensitivity of mammalian cells to ionizing radiation.

Caffeine treatment reduces ionizing radiation-induced cell-cycle delay, affecting cells in the G1, S and G2 phases of the cell cycle ${ }^{2,5}$. Caffeine seems to stabilize factors required for progression through the cell cycle $^{6}$, and inhibits induction of p53 after radiation exposure ${ }^{2}$. Caffeine treatment can enhance radiotoxicity; however, this occurs primarily during G2 phase ${ }^{7}$ and does not show a correlation with reduced cell-cycle delay ${ }^{8}$. In addition, the timing of the caffeineinduced increase in chromosome aberrations in normal human lymphocytes

\footnotetext{
Hartwell, L. Cel/71, 543-546(1992),

2. Kastan. M. B. etal. Cancer Res.51, 6304-6311 (1991).

Kastan, M. B. et al. Cel/ 71, 587-597 (1992)

. Kastan, M. B. et al. Cell 71,587-597(195

5. Tolmach, L. J., Jones, R. W. \& Busse, P. M. Radiat. Res. 71, 653-665 (1977).

6. Schlegel, R. \& Pardee, A. R. Proc natn. Acad Sci. U.S.A 84, 9025-9029 (1987)

Busse, P. M., Bose, S. K., Jones, R. W. \& Tolmach, L. J. Radiat. Res. 76, 292-307 (1978).

8. Musk. S. R. Radiat. Res. 125, 262-266 (1991).

9. Natarajan, A. T., Obe, G. \&Dulout, F. N. Hum. Genet. 54, 183-189(1980).

10. Murnane, J.P. \& Kapp, L. N. Sem. Cancer Biol. 4 93-104 (1993).

11. Painter, R. B. \& Young, B. R. Proc. natn. Acad. Sci. U.S.A. 77, 7315-7317 (1980)
}

does not show a correlation with the G1 checkpoint ${ }^{9}$.

AT cells are similar to caffeine-treated cells in that they are highly sensitive to ionizing radiation and show reduced cell cycle delays in $\mathrm{G} 1, \mathrm{~S}$ and $\mathrm{G} 2$ phase $^{10}$. As with caffeine-treated cells, the absence of a radiation-induced G1 delay in AT cells is associated with a failure to induce p53 protein $^{2}$. Although abnormal cell-cycle regulation was originally proposed as the mechanism of radiosensitivity in AT (ref. 11), several lines of evidence suggest that this is not the case. (1) Delaying cell-cycle progression in AT cells does not enhance survival after exposure to ionizing radiation $^{12}$; (2) AT cells show increased chromosome damage immediately after ionizing radiation exposure without progression through the cell cycle ${ }^{13}$; and (3) the radiation hypersensitivity and abnormal cell-cycle delay in AT are separable phenotypes $^{14-16}$.

Studies with transformed cell lines also indicate a minor role for $\mathrm{p} 53$ and the G1 checkpoint in radiation sensitivity. SV40transformed cells, in which $\mathrm{T}$ antigen inactivates p53 (ref. 17), do not show increased cell killing after ionizing radiation $^{18}$. Further, the variability in cell survival in human tumour cells in response to ionizing radiation ${ }^{19,20}$ does not correlate with the presence of $\mathrm{p} 53$ mutations ${ }^{20}$. Sensitivity to radiation-induced chromosome aberrations after exposure of tumour cells in G1 phase is also apparently independent of p53 (ref. 19).

In view of these studies, it seems highly unlikely that the genomic instability associated with p 53 mutations is due to the cell's failure to repair DNA damage before attempting DNA replication. Genomic instability must therefore result from other complications of defective cell-cycle regulation or one of the many other cellular pathways affected by $\mathrm{p} 53$ mutations.

\section{John P. Murnane}

Laboratory of Radiobiology and

Environmental Health,

University of California, San Francisco,

California 94143-0750, USA

Jeffrey L. Schwartz

Centerfor Mechanistic Biology and

Biotechnology,

Argonne National Laboratory,

Argonne, Illinois 60439-4833, USA

\footnotetext{
12. Cox, R., Masson, W. K., Weichselbaum, R. R., Nove, J. \& Little, J. B. Int. J. Radiat. Biol. 39, 357-365 (1981).

3. Cornforth, M. N. \& Bedford, J. S. Science 227, 1589 1591 (1985).

14. Kapp, L. N. \& Painter, R. B. Int. J. Radiat. Biol. 56. $667-675$ (1989)

15. Lehmann, A. R. et al. int. J. Radiat. Biol. 49, 639-643 (1986).

16. Komatsu, K., Kodama, S., Okumura, Y., Koi, M. \& Oshimura, M. Mut. Res. 235, 59-63(1990).

17. Bargonetti, J., Friedman, P. N., Kern, S. E., Vogelstein, B. \&Prives, C. Cell65, 1083-1091 (1991).

18. Arlett, C. F., Green, M. H. L., Priestley, A., Harcourt, S. A \& Mayne, L.V. Int. J. Radiat. Biol. 54, 911-928 (1988)

19. Schwartz, J. L. Radiat. Res. 129, 96-101 (1992).

20. Brachman, D. G. etal. Cancer Res. 52, 4832-4836 (1992).
} 